\title{
THE PRINCIPLE OF COMPETITIVE COST IN PUBLIC UTILITY REGULATION
}

\author{
JoHN E. KIRSHMAN
}

Regulation of public utilities in the United States has as its deepest purpose the perpetuation of ideals and standards attained in the field of natural competition. Any other presumption or conclusion would ignore the fundamental principles of Ameriean industrial development and place the purposes of law and economics at variance. American constitutional and legal principles, insofar as they relate to economic matters, are in reality but the crystallization of common customs and practices developed in the growth and advancement of American economic enterprise. These can form the only enduring basis of law in the field of economics, as customs and practices in politics, society, and religion form the basis of law in their respective fields. Regulation of public utilities, therefore, must be viewed from the standpoint of the hinterland of general economic development and legislation.

\section{THE BACKGROUND OF REGULATION}

Industrial America has been built upon the competitive ideal. Although the competitive ideal itself reaches back to old world customs and practices, it nevertheless found in the development of this country a fertile field in the deep-rooted individualism and personal freedom evolved out of the pioneer economic conditions of frontier life. The ideal of economic competition, a development of the old world, was rejuvenated by a virile individualism that taught the precept of reward for effort. This was the dominating motive of American industrial life throughout the nineteenth century and has continued to energize American business men in the building up of the great corporate entities of the twentieth century. It is thus still recognized as the mainspring of progress and, in spite of its inperfections, is in no immediate danger of being displaced by any other ideal.

The competitive ideal has also been the touchstone of American economic legislation. It has moulded state corporation laws and state and federal free banking laws. Tariff legislation has as its guiding principle the maintenance of fair competition between American and foreign industries. Federal and state anti-trust laws and the Federal Trade Commission have as their main purpose the maintenance of equal and fair competitive conditions. Likewise, the Transportation Act of 1920 dealing with railroads requires that "competition shall be preserved as fully as possi- 
ble." 1 Even the leading political parties have been a unit on this fundamental question, although they have at times differed as to the form which competition was to take, since it is still a matter of uncertainty just how far large-scale production can proceed to advantage. Likewise, labor unions, although opposed to individual freedom, insist upon collective freedom of contract in dealing with their employers. More fundamentally, the Constitution of the United States itself guarantees the freedom of occupation when it declares that no person "shall be deprived of life, liberty, or property without due process of law." "

\section{ORIGIN AND DEVELOPMENT OF UTILITY REGULATION *}

The early cases of English regulation show the efforts of the government to maintain or restore competitive conditions. In the first important case ${ }^{3}$ of regulation brought in the American courts, decided in 1876, the Supreme Court cited several early English cases discussed by Chief Justice Hale in Partibus Maris, ${ }^{4}$ dealing with ferries, wharves, and warehouses each of which was said to have a monopoly or was strongly affected by monopolistic elements. In the case of Munn $v$. Illinois itself the decision that grain elevators were subject to regulation rested on the "virtual monopoly" of the owners of the elevators. " The fact of monopoly in a public necessity constituted the reason why property became clothed with a public interest and "used in a manner to make it of public consequence, and affect the community at large." "

It is true that in the early English cases reasonable rates or charges specially referred to the price of the service rather than to the profits accruing to the owners of public conveniences. In economics, however, public utility services of all description come under the class of services with inelastic demand, which means that the demand varies but little, if any, with a change in price. It is probable, therefore, that in the cases referred to the control of rates resulted in the restoration of competitive prices and profits, for English industry, like American, was developed on the basis of free competition expounded by Adam Smith, the father of English political economy, in his book, The Wealth of Nations.

Regulation of public utility corporations is concerned not with one competitor against another, but aims at vouchsafing the results of competition to the public as users of the service and to investors who furnish the capital for rendering this service.

\footnotetext{
${ }^{1}$ Act of Feb. 28, 1920, c. 91, sec. 407 (41 Stat. at L. 48, cl. 4).

2 Fifth Amendment to the Constitution of the United States.

${ }^{3}$ See Munn v. Illinois (1876) 94 U. S. 113.

41 Hargrave, Law Tracts, 78.

5 See Munn v. Illinois, supra note 3.

B Ibid. at 126; Rottschaefer, The Field of Governmental Prico Control (1926) 35 Yale LaW JouRNax, 438.
} 
These results are the maintenance of a competitive price, a competitive return on capital, and competitive standards of service. Now all of these results have been endangered by the lack of natural competition in public utility enterprises.

The story of consolidation in the public utility field is too long for even a brief review in this article. It is necessary, however, to emphasize that consolidation in this field has as its basis the fact that public utility industries are naturally monopolistic in character. Wherever inherent economic forces are strong enough ultimately to eliminate all competition a natural monopoly exists. Public utilities are naturally monopolistic because where two or more competing companies render the same service, both striving after the patronage of the same consumers, the natural result must necessarily be vast duplication of capital and effort, not to speak of the many disadvantages of small-scale production. An attempt to maintain competition under these circumstances vould be artificial. The duplication and wastes of artificial competition in a naturally monopolistic field result only in raised prices, reduced profits, and deteriorated service. The accusation of high profits in days before regulation came was in many cases justified; nevertheless profits were not as high as they would hare been had not wasteful competition entered into the situation. Competition always defeats itself when it is introduced into a field where natural monopoly holds sway. When it proceeds far enough service begins to deteriorate in an effort to halt waning profits. Too often this results in financial reverses for the corporations, and poor service and high prices to the publie. The impelling force of greater gains and public dissatisfaction with poor service finally led to consolidation and united enterprise. Thus artificial competition could not be made to work successfully in a naturally monopolistic field. In its efforts to maintain or restore competitive standards, regulation in many instances could but seeli manifest objectives. Yet the competitive principle itself has been the marrow and bone of regulation. Its tendeney is toward reduced prices, fair profits, and satisfactory services.

\section{COST-OF-SERVICE STANDARD}

A competitive standard is a cost standard. Where two or more producers are competing for the sale of the same article, and that article is capable of being reproduced in unlimited quantities, the price will tend to settle at the cost of production. This, however, is not the cost to the marginal or high cost producers, as is often erroneously imagined; it is the cost to the most efficient producer who in time increases the volume and reduces the price of his product to the extent that inefficient producers whose costs exceed the price are driven to the wall. The result is that the least cost in the long run becomes the standard or competitive cost, and the 
public gets the service upon the best terms possible. It is this cost-of-service principle, that regulation is striving to preserve. Regulation, however, must not be so parsimonious as to dry up the sources of capital or put a damper upon personal incentive, the penalty of which is ultimately inadequate and costly service.

To come to more concrete matters, it may be asked, what are the ingredients of a competitive cost price? Broadly speaking they may be classified as wages of labor and management, cost of raw materials and supplies, taxes, and capital charges. The economic problem of public utility regulation is largely the problem of meeting competitive wages of labor and management, competitive costs of materials and supplies, taxes, and a competitive return to the capital invested. All of these costs, except taxes, are presumably determined to a large extent by competitive conditions in industry at large. Although there are monopolistic influences at work in industry at large in the form of labor unions, outside of railroads, these have had little direct influence on the wage scale in public utilities in general. In the case of railroads the conditions are exceptional in that the unions exercise a considerable control over wages, as also does the Federal Railroad Labor Board. Likewise, materials and supplies are purchased for the most part in a competitive market.

Even to a.greater extent than wages, materials, and supplies, the return to capital is determined by competitive conditions. No market is so free from artificial or natural hinderances to free choice as the capital market. Capital flows freely to the point of least resistance or greatest return. All that capital demands in the public utility business is a return comparable with that roceived by capital invested in competitive enterprise, after making due allowance for the risk involved in each case. This principle will insure that the public utility industry will always be able to attract its proportionate share of current capital funds. This great principle of natural regulation apportions capital, as also labor and supplies, to the various points in the general field of economic enterprise where the need is greatest, and thereby produces a balanced industrial system. This is the ideal after which regulation should and in the end must strive if the public is to be supplied with the service demanded and if the growth of public utilities is to keep pace with the general growth of the country. A return sufficient to attract a due proportion of current capital funds to the public utility field may be regarded as the sine qua non of regulation.

\section{MODERN REGULATION}

Early American state laws fixing railroad rates were passed with a view to preventing exorbitant and discriminating rates. In their eagerness to protect the shipper, rates were arbitrarily 
fixed without much regard to their profitableness to the railroads. This brought appeals to the federal courts for the protection of the railroads. In its consideration of grounds for interference, the Supreme Court rested its case on the Fifth and Fourteenth Amendments to the Constitution. The Fifth Amendment provides that no person shall be "deprived of life, liberty or property", without due process of law; nor shall private property be taken for public use without just compensation." This Amendment applied only where federal jurisdiction over persons held sway. The language of the Fourteenth Amendment reads as follow: "Nor shall any State deprive any person of life, liberty, or" property without due process of law." This amendment, however, was adopted with reference to reconstruction in the South following the Civil War and apparently had no reference to public utilities. The Supreme Court, however, after long consideration finally came to the conclusion that "due process" also included "just compensation", although the latter phrase was omitted from the Fourteenth Amendment entirely. Thus the federal courts came into the general field of public utility regulation.

Little progress in regulation was made for the next decade. The stringency of state laws in fixing rates, however, led the Supreme Court to declare in 1885 that, "This power to regulate is not a power to destroy and linitation is not the equivalent of confiscation." : In view of this decision, railroads pressed their claim that their property was being confiscated; and it was thus incumbent upon the Court to assume some responsibility in deeiding when rates were reduced to the point of confiseation. In Chicago, Milwaukee and St. Paul Railu'ay r. Minnesota." deeided in 1890, the Supreme Court held that it was within the power of the courts to decide when a rate fixed by a state was illegal or unreasonable. But what standard or yardstick should the courts use in deciding such cases? Where should confiscation begin? In an important case, decided in 1894, the Supreme Court said, "justice demands that every one should receive some compensation for the use of his money or property, if it be possible, without prejudice to the rights of others." " It was argued in several cases at the time that to deprive the owner of the return on his capital in effect deprived him of the uses of capital, and hence of the capital itself. It was further argued that the return should be on all of the capital and that a small return was equivalent to a reasonable return on only a part of the capital, the remainder going without any compensation whatever. This compelled the

'Stone v. Farmers' Loan and Trust Co. (1880) 116 U. S. 307, 6 Sup. Ct. 334, 388, 1191.

s (1890) 134 U. S. 418,10 Sup. Ct. 462.

${ }^{9}$ Reagan v. Farmers' Loan and Trust Co. (1893) 154 U. S. 362, 14 Sup. Ct. 1047. 
Court to establish some standard as to what a reasonable return on the entire amount of the capital should be. This was finally decided in 1898 in the classic case of Smyth $v$. Ames ${ }^{10}$ where it was said that, "What the company is entitled to ask is a fair return on the value of that which it (the corporation) employs for the public convenience."

Undoubtedly the Court used the term "fair return" in the same sense as it had frequently employed the term "reasonable return". The Court for the first time thus definitely read into the term "reasonable rates" the meaning that rates to be reasonable must not only be fair to the ratepaying public, but also high enough to give a reasonable return on the capital invested. Reasonable return meant nothing more than a competitive return on the capital employed. In future cases this point was abundantly amplified, as will be shown later.

The Court at this point, however, failed to identify the idea of a competitive return to capital with competitive cost, or simply cost of capital. It either failed to understand that under a system of competitive industry all costs and rewards are competitive, and but for the force of competition, costs would be far different from what they are, or it shrank from the consequences of recognizing the principle. If the return to capital were a cost similar to other expenses of production, it would devolve upon the courts, or some other authority, to determine what the capital investment was and to inquire into the circumstances that effect the competitive cost itself. Such a task neither the courts nor any other body at that time had the courage to contemplate. It would have involved an enormous amount of work such as the Interstate Commerce Commission is doing in the valuation of railroads-a task clearly beyond the range of possibilities at that time.

Yet this is what regulation logically leads to. The capital costs of an enterprise are just as truly competitive as the cost of labor, management, raw materials, and supplies. Wages are what they are because of competitive forces in the labor market. Where competition is free, wages tend to equalize at the competitive figure, as also do the costs of raw material and supplies. The only difference between capital and other costs is that capital costs, more than other costs, involve the time element. Yet this time element varies from a few weeks or months to many years. Interest on bank loans has always been regarded as a part of the expenses of operation by the courts and commissions, regardless of the length of time which loans run. The fact that these loans are frequently and sometimes habitually renewed without the semblance of being paid makes no difference. All notes running a year or less are treated in the same way. But when it came to long-time borrowing and ownership securities, the Court failed

10 (1898) 169 U. S. 466, 18 Sup. Ct. 418. 
to apply the competitive principle, and thus missed the true prineiple of cost which lies at the basis of capital supply.

On the contrary the Court, consciously or: unconsciously, took the easy way-easy as it appeared then, but which, as it subsequently proved, led to the tangled web of valuation and depreciation. It laid down the principle of fair valuation as the basis upon which the fair or reasonable rates should be determined. Although the principle was first definitely laid down in Sizyth $i$. Ames, ${ }^{11}$ is was best expressed in a later case:32 "The property is held in private ownership and it is that property, and not the original cost of it, of which the owner may not be deprived without due process of law." It was thus the current value of the property that was to be the basis of calculation of reasonable return. It should be observed that this was in no way required by the Constitution, but represented the only feasible path for the Court to pursue, for the task of inding original cost was hopeless in the absence of dependable financial records. Present value could be approximately obtained by the comparative method. The Court was doubtless influenced also (to what extent one can only guess) by the long-established custom in condemnation cases. In these instances, the value of property was the result partly of the current and prospective earning power of the property under consideration. The Court's problem in such cases was the determination of sale, or market, value. But the significant fort for present purposes is that the Court did not perceive that a rate base which rested upon current value had no relation to cost; and it thus hopelessly diverted the course of regulation into the traelless wastes of reproduction cost, going concern value, ete. The greatest task now before the courts is to find the way back to the principle of competitive capital costs. Without this there is no sound basis for dealing with the problem of the return to capital. Investors will continue to rest uneasy until the present uncertainty in valuation has been replaced by the cost principle.

\section{VALUATION OF PUBLIC UTILITY PROPERTY}

The principle of current valuation now required by the courts is fraught with great consequences to investors. While it was not necessary for the courts to find a new meaning for the term "value", as is sometimes erroneously thought, it was necessary to devise a method of finding what that value was. It could not appeal to the sale value, for public utility property is not bought and sold like movable property or real estate. The task then was to seek a method of valuation-to analyze the elements of value. A solution was arrived at in Smyth 2 . Ames ${ }^{13}$ and stated in the

11 Supra note 10.

12 Simpson v. Shephard (1912) 230 U. S. 352, 33 Sup. Ct. 729.

13 Supra note 10. 
following language: "The original cost of construction, the amount expended in permanent improvements, the amount and market value of its bonds and stocks, the present as compared with the original cost of construction, the probable earning capacity of the property under particular rates prescribed by statute, and the sum required to meet operating expenses, are all matters for consideration and are to be given such weight as may be just and right in such case. We do not say that there may not be other matters to be regarded in estimating the value of the property."

Let us examine briefly each of the elements of value as laid down by the Court. Consider first earning power. The relation between earning power and capital value is not nearly so close as is often assumed in economic and judicial opinion. This theory depends upon the capitalization of earning power, and implies a specific rate of capitalization in each case, which is almost impossible of realization in practice. But the main error in this view lies in the misapprehension that the ability of a business concern to show satisfactory net earnings depends solely upon the productive power of the capital invested. It ignores the function of management, the efficiency of the labor force, and the extent to which the organization may possess monopolistic privileges.

Closely related to this matter is the general assumption that the market value of the stocks and bonds of a corporation is the true measure of the value of its property. This error is based upon two fallacies: first, it is assumed that the price of securities depends upon earning power; and second, that the earning power of a corporation is tantamount to the earning power of the capital. It has already been pointed out that capital has no-independent earning power of its own. It remains to be pointed out that the price of bonds and stocks is only indefinitely related to earning power. The market value of safe bonds is immediately the result first, of certain contractual provisions relating to the nominal rate of interest, maturity date of the bonds, and other contractual details; second, bond prices vary according to conditions prevailing in the general money market at any particular time. The price of preferred stocks and second-rate bonds is affected by the same forces that affect safe bonds, but in addition is influenced by the state of the earnings of the corporation. Common stocks are influenced to some degree by general money market conditions, but more largely by the amount of the residual earnings of the corporation after all expenses and fixed interest and preferred stock dividend charges have been met, as also upon surplus, dividend policy, and matters relating to control. Since on the average public utility property is represented to the extent of three-fourths of its value by bonds and preferred stocks, the relation between the earning power and market value of the total capitalization is only a remote one. 
The principle of reproduction value has possessed special fascination for the courts because it comes more nearly to the concept of sale, or exchange, value which is the common, as well as the traditional meaning of the term "value". Aside from the technical engineering difficulties in the way of ascertaining reproduction value, there are two fundamental objections to its use as a basis for rate-making. In the first place, even if reproduction value could be easily and accurately ascertained, it would not represent an element of cost in the production of utility services. In the second place, as applied by the courts in recent cases, the principle has become ludicrous in its hypotheses and conjectures. In the Bluefield Water case, the Court set aside the commission's valuation because it "did not accord proper, if any, weight to the greatly enhanced costs of construction in 1920 over those prevailing about 1915 and before the war." ${ }^{14}$ As to how much the commission should have added so as to pass muster, the Court did not undertake to say. In the Southzestern Bell Telephone Company case, however, the Court required that the commission's valuation be scaled up "at least" 25 per cent.15 How much more should be allowed is not stated, although it was recognized that to malie due allowance for advance in the price level $45 \%$ or $50 \%$ would be necessary. Still more recently a federal court insists that reproduction cost be the dominant factor in determining the fair value of property. ${ }^{10}$

Although the courts insist upon the principle of reproduction cost, commissions since 1920 have almost universally either disregarded it entirely or given it only minor weight. Out of three hundred and sixty-five cases reported in Public Utility Reports Annotated from the beginning of 1920 to MIarch 1, 1923, in all but five the commissions neglected this element of value entirely or gave it only small weight. In only five cases was it the predominating factor. ${ }^{17}$ The reason for this almost universal disregard of reproduction value is that such a valuation unduly enhances the rate base beyond the actual cost of the property, and results in greatly increased revenues to the corporations. Although the opposite course would have been to the immediate advantage of the security holders, the course of the commissions on the whole has been wise. Should reproduction cost be recognized as the predominating principle in valuation and should prices fall in the Iuture, its application would work great injury to investor's. It

is Bluefield Wraterwarlis \& Improicmont Co. 2. Public Scri. Comm. (1983) 262 U. S. 679,43 Sup. Ct. 675.

15 Mrissouri v. Public Seivice Commission (1923) 262 U. S. 276, 43 Sun. Ct. 544.

15 Nev York and Richmond Gas Co. v. Prendergast (1025 E) Pub. Util. Rep. (E. D. N. Y.) 19.

1: See, Investment Bankers' Association of America, Bulletin of June 30. 1923, p. 275 , note. 
is sometimes claimed that reproduction cost would be in harmony with changes in the purchasing power of the dollar, and that whether prices advanced or receded the investor would be left in the same relative position as before. Although the truth of this argument cannot be questioned, it may be fairly asked why the public authority should undertake to guarantee a constant purchasing power in this instance when nowhere else is effort made to that end. It surely is not incumbent upon state and federal governments to give this special guarantee to investors in public utility securities. Neither of these governments undertakes to do as much with respect to its own obligations. To do so would also be a departure from the principle of service at cost.

Whatever criticism may be made of the present court requirements, and however great the consequences to investors, it is of secondary importance to the one fundamental requirement that rate regulation rests soundly upon the principle of the competitive cost of capital. Thirty years of regulation and development of public utilities have vastly increased the importance of regulation itself. Something like one-fourth of the productive capital of the country is under regulation. Where we once had poor accounting and secrecy, we now have standardized accounts and publicity. Where costs were once a mystery even to those who were most concerned, they are now as open books. Where financial plundering was once condoned and even looked upon as a mark of shrewdness, it is now justly condemned by an enlightened business and financial conscience. Where capital was once provided by a scant few, it is now furnished literally by millions of investors directly, and many other millions indirectly through insurance companies, savings banks, and other institutions. Where we once had a simple capital market, we now have a complex one. These circumstances and many more have irrevocably altered the point of view in rate regulation and demand the adoption of sound principles of procedure.

The principle of original prudent investment cost has come to be widely advocated as a rate base. The advantages of this as a rate base are forcibly set forth by Mr. Justice Brandeis in the dissenting opinion in the Southwestern Bell Telephone Company case. ${ }^{18}$ This principle seems to fit modern requirements and conditions better than any other. In view of the control now exercised over security issues, the investment cost would be approximately equal to the par value of the securities outstanding. It would also be unaffected by changing price levels and cost of equipment. When an investment is once made and the securities issued, they remain definite in amount; and a return sufficient to pay interest and dividend requirements on this amount would remove most of the uncertainty from the present situation.

${ }^{18}$ Supra note 15. 
The application of this principle may be seen in the recent case of the New England Telephone and Telegraph Company. Fiegulation in MIassachusetts has from the first included control over security issues so that the question of watered stock is not a problem of great consequence. In this case the par value of the securities outstanding represented the judicious eapital outlays in the past. It was said that the state "has proceeded upon the theory that these securities thus issued constitute the proper rate base. Stated tersely, it is the money honestly and prudently invested and devoted to the public service that is entitled to earn a fair return." 29 The example of MIassachusetts with its enviable reputation for sound principles in utility regulation may well be imitated by other commonwealths. This is the road which the courts should seek out of the present tangle of valuation.

\section{DEPRECLATION}

The final word on the present practice of valuation cannot be said without consideration of the important matter of depreciation. Valuation figures may be greatly altered by the treatment accorded depreciation facts. The two broad divisions into which the general subject of depreciation in public utility properties may be divided are (a) physical and (b) functional depreciation. These types of depreciation are wholly different in their nature, and must be treated differently in rate-making. Physical, or theoretical, depreciation exists when a given period of the service life of a plant has elapsed. Assuming that the entire period of the service life is ten years, after the lapse of five years theoretical depreciation to the extent of 50 per cent of the value of the plant would exist. Nevertheless, and provided the plant has been well maintained in the interval, there would be no loss in eficiency or service value. On account of this fact depreciation in this sense has sometimes been called decretion because of the gradual physical deterioration."

Functional depreciation may be distinguished from theoretical depreciation by the fact that equipment in whole or in part may be superseded by more efficient inventions redueing the cost of service or giving better service at the same or a difierent cost. In this event depreciation is due to obsolescence. Functional depreciation may also take place because the growth of a community renders the old plant and equipment inadequate to take care of the increased needs. It may also take place on account of regulatory or legal requirements which the existing plant cannot meet. In each of these cases the plant may still possess undiminished service value.

\footnotetext{
19 IIass. Department of Public Utilities, $R_{0} N c z$ Englend Telcpherac cazd Telegraph Co. (1925E) Pub. Util. Rep. (MIass.) 739.

${ }_{20} \mathrm{Cf}$. Riggs, Depreciation of Public Litility Projerties (1929) Ch. 11.
} 
There has been much confusion on the subject of theoretical, or physical, depreciation. Neither the courts nor the engineers have been in agreement even among themselves on this question. Yet theoretical depreciation as just explained must be distinguished from loss of service value. A plant loses service value when the management has failed to make proper repairs and replacements, thereby reducing its ability to give standard service. Where courts and commissions have clearly made this distinction they have claimed the right to reduce valuation figures by the amount necessary to place the plant in standard service condition. At the same time they have refused to reduce valuations on account of theoretical depreciation. ${ }^{21}$ In a recent case a federal court said,"2 "The mere elapse of time since the plant was established or its units have been installed has not been shown to have decreased the value of the property as a whole as it stands today." In this case nothing was deducted for theoretical depreciation. Some form of penalty for failure to maintain property in first-class condition is doubtless desirable. Yet this form of penalty does not meet the situation, for property in a rundown condition will require increased operating expenses out of all proportion to the expenditures necessary to restore it to standard condition. The most effective remedy here is not to penalize the security holders, as this method of treatment does, but to require that property be maintained in standard service condition at all times.

There has also been much disagreement as to the treatment of purely theoretical depreciation where the plant has been maintained in the best condition. Neglecting former practices in this matter, it may be said that regulatory bodies now distinguish between cases where a reserve is carried and those where no reserve is carried. The former method is called the allowance method, while the latter is referred to as the replacement method. Where the reserve method is used, deductions are made annually from operating revenues sufficient to amortize the cost of the equipment or part at the end of its service life. Where the reserve is reinvested in the plant in the form of extensions or betterments, courts and commissions now quite generally make no deductions from valuation figures to take care of depreciation." ${ }^{.3}$ But where it is otherwise invested, the amount of the depreciation fund may properly be deducted from the valuation to find the

${ }^{21}$ See New York and Queen Gas Company v. Newton (1920, S. D. N. Y.) 269 Fed. 277.

${ }^{22}$ New York and Richmond Gas Co. v. Prendergast, supra note 16; Ro J. H. Perry (1925 E) Pub. Util. Rep. (Utah) 161.

${ }^{23}$ Michigan Pub. Util. Comm. v. Michigan State Telephone Co. (1925 C) Pub. Util. Rep. (Mich.) 158; Monroe Gas Light and Fuel Co. v. Michigun Pub. Util. Comm. (1923 E) Pub. Util. Rep. (Mich.) 661; Cf. Cincinnati v. Public Util. Comm. (1925 E) Pub. Util. Rep. (Ohio) 432. 
rate base. Where the replacement method is used no reserve for theoretical depreciation is carried, but only an amount sufficient to replace parts or units of equipment as it becomes necessary to keep the plant in standard service condition. The plant is thus regarded as a continuing unit with an indefinite life period; and as long as it remains up to standard condition no loss in service value results.

It does not seem that either of these methods of treatment would necessarily work injustice to the security holders, for the rate base would remain the same as the original or prudent cost of the plant. Injury would come, however, where the regulatory body confuses these methods so that while attempting to apply the replacement method deduction is also made for the comparatively small reserve carried. In the replacement method the fund must of necessity be kept in liquid form so that it will be available at all times for the purpose for which it is intended. While some deduction may justly be made in view of this as an earning fund, deduction beyond this amount would result in an inadequate rate base.

It should also be observed that in case of the allowance method of treating depreciation, where the fund is invested in extensions the public profits by receiving the services of a larger amount of property than that represented by the rate base. Theoretically it is sounder than the replacement method on the further ground that it requires the current users of service to pay all legitimate operating expenses. The present tendency of the courts away from the allowance method of treating depreciation cannot be looked upon with entire approval.:a

\section{FUNCTIONAL DEPRECLATION}

The above considerations apply only to theoretical depreciation. Functional depreciation must be treated in a different manner. It should first be observed that in competitive industry funetional depreciation occurs when old equipment becomes either obsolescent or inadequate on account of newer inventions and processes which place their users at an advantage over competitors who continue to use the older equipment. Competition will of course finally force the abandonment of older equipment. Since competition is normally absent in public utilities there is no functional depreciation here in this sense. There is, however, a form of competition among the users of the service, a sort of social competition which leads the public of any given community to demand service equal to or better than that of other communities. Old service units may for this reason have to be abandoned in favor of the newer and better units. But this can hardly be

\footnotetext{
${ }^{24}$ See Cooke, Public Utility Regulation (1924) Chapter on "Major Problems Presented to State Commissions" by Donald R. Richberg, 6G-67.
} 
called depreciation. New service units replaced for this reason should legitimately be charged to the rate payers who get the benefit of the better service. The charge should be sufficient to provide interest on the additional capital installed and an annual charge on operating expenses to provide an amortization fund for the discarded equipment. The principle of charging the costs of better service to those who benefit from such service has special application where it is required on account of regulatory measures.

ITachinery and equipment superseded by units more efficient from the point of view of cost in producing service may profitably replace the older units when the saving in operating expenses is sufficient to pay interest on the additional cost of the newer machinery and to provide an amortization fund for the balance of the service period of the older machinery and equipment. This is the only sound economic basis for discarding machinery which operates only at a high cost. In case of replacement on account of sheer inadequacy of the older plant to perform the service required by a growing community, it is no more than just that the future users of the service should stand the additional costs of enlarging the facilities.

In all cases of functional depreciation it will be observed that it is only the future and never the past which is affected. In every case the burden ought to rest upon the future rate payers. It appears, therefore, that a reserve for functional depreciation would be out of place prior to the discarding of the obsolete or inadequate machinery and equipment.

The treatment of depreciation on account of obsolescence and inadequacy by engineers has been diverse in character and very unsatisfactory in its results. To quote Professor Riggs," "One will discard it entirely, another will consider it and possibly modify his figures slightly on account of the previously obsolete character of certain units of property, while a third will make heavy deductions in arriving at fair value." The courts have dealt only sparingly with this type of depreciation, but have in a few instances refused to allow deduction therefor..$^{23}$

\section{RATE OF RETURN TO CAPITAL}

To return to the main point of the discussion, no matter what rate base is chosen, the return on the capital invested must be sufficient to maintain the credit of the corporations and to attract new capital to public utility enterprises. This requirement cannot be compromised, for utility enterprises under regu-

25 Op. cit. supra note 20 , at 132.

${ }^{2}$ Cf. Kansas City Southern Railway Co. v. United States (1013) 281 U. S. 423, 34 Sup. Ct. 125; also Special Master Gilbert's report in Now York and Queens Gas Company v. Newton, supro note 21. 
lation depend not upon surplus earnings for expansion purposes, but at all times depend upon the investing public. It may appear upon first consideration that the rate base is comparatively unimportant, provided only a sufficiently high rate of return is allowed in order to meet competitive capital charges and maintain the credit of the corporation. In a purely abstract way this may be correct; but in practice the actual rate allowed is beyond doubt greatly influenced by customary figures, regardless of their adequacy to meet conditions in the capital market. Although starting from some method of valuation of property to seeure a rate base, commissions have usually attempted to secure a valuation which when combined with a given rate will be suffieient to meet competitive requirements. Although under prevailing judicial decisions this has been the only course open to commissions, it must be emphasized that it does not constitute a sound basis for rate-making. It rests too much responsibility upon the commissions which are bound to steer clear of the rock of too high rates on the one hand and confiscation on the other. The rate of return allowed really means nothing under the present situation of an elastic rate base.

In spite of the unsound rate base at present required, the ccurts have in general proceeded along sounder lines with reference to the rate of return allowed on the property devated to the public convenience. They have quite generally insisted upon the competitive principle as the measure of the rate of return. In Wincox $v$. Consolidated Gas Company ${ }^{2 z}$ the Suprene Court recognized the two broad principles that lie at the bottom of a reasonable rate of return. It pointed out that local money conditions and the risk of the individual enterprise compared with other enterprises were the determining factors in a reasonable rate. It compared the risks in the gas industry in its early days with the comparative security at the present time, indicating that a reasonable rate would have been much higher in those early days than at present. The principle is stated more in detail in the following extracts:

"A public utility is entitled to such rates as will permit it to earn a return on the value of the property which it employs for the convenience of the public equal to that generally being made at the same time and in the same general part of the country on investments in other business undertakings which are attended by corresponding risks and uncertainties; but it has no constitutional right to profits such as are realized or anticipated in highly profitable enterprises or speculative ventures. The return should be reasonably sufficient to assure confidence in the financial soundness of the utility and should be adequate, under efficient and economical management, to maintain and support its credit

$2 \pi$ (1909) 212 U. S. 19, 29 Sup. Ct. 192. 
and enable it to raise the money necessary for the proper discharge of its public duties." 28

"It has been held that no rate of return can be deemed reasonable which is not high enough to attract capital to the form of investment involved in utility properties, such as complainant's."

"There is a hazard attached to a utility investment which has no guaranty of a return, that does not attach to a well-secured real estate mortgage, and it is entitled to a return to compensate it for that risk.

"In addition to the normal hazards of business a utility has over it at all times the risk that some State or Federal Commission may make a mistake and compel it, for a time at least, to operate at a loss." 30

"Again, telephone companies must grow on an ever-increasing scale in order to meet the demands of the public for service. Under the theory that only a fair return is permitted upon the property used and useful in giving public service, the utility must make extensions out of new capital. Unless money representing the investment in the property already made is earning a reasonable rate of return, commensurate with the going rate for money invested in property of approximately like risk, new money cannot be obtained." 31

In Ames $v$. Union Pacific Railroad Co.32 the court strongly emphasized the necessity of doing justice to investors in railroads. In the Lincoln Gas case ${ }^{33}$ the court said "Annual returns on capital and enterprise the world over have materially increased, so that what would have been a proper rate of return for capital invested in gas plants and similar public utilities a few years ago furnishes no safe criterion for the present or for the future." Finally, the memorandum of the commissioner in the Southwestern Bell Telephone case $^{34}$ before the Kansas Supreme Court may be cited as an expression of a sound attitude: "A public utility . . . must run the gauntlet of good and bad times, strikes, fires, and revolutions in the arts. . . . In addition to the normal hazards of business a utility has over it at all times the risk that some state or federal commission may make a mistake and com-

\footnotetext{
${ }^{28}$ Bluefield Water Works and Improvement Co. v. Public Serv. Comm., supra note 14.

${ }^{29}$ Alton Water Co. v. Illinois Commerce Comm. (1922, S. D. Ill.) 279 Fed. 869.

${ }^{30}$ Southwestern Bell Telephone Co. v. Public Util. Comm. (1924) 115 Kan. 236, 223 Pac. 771.

31 Re Mountain States Telephone and Telegraph Co. (1922 E) Pub. Util.

Rep. (Utah) 293.

32 (1894, C. C. D. Neb.) 64 Fed. 165.

${ }^{33}$ Lincoln Gas and Electric Light Co. v. City of Lincoln (1919) 250 U. S. 256, 40 Sup. Ct. 585.

34 Supra note 30.
} 
pel it, for a time at least, to operate at a loss." The importance of allowing a liberal rate in view of competitive conditions in the capital market is further emphasized by the refusal of the courts to allow deficits incurred through insufficient rates in the past to be subsequently made up. On the other hand the Interstate Commerce Commission ${ }^{36}$ works on the principle of average rate of return in good and bad years.

While the decisions and opinions above cited show clearly that the courts work on the principle of competitive cost of capital in fixing a rate of return, they nevertheless fail to carry the principle to its logical conclusion. The principle of competitive capital cost demands only that the return shall be sufficient to meet the conditions of the market at the time the securities are being floated. Contracts once made remain unchanged, and a return sufficient to meet the contract requirements will always be adequate. As each new issue of securities is floated care must be taken that the future earnings will be large enough to meet the new costs incurred.

The application of these principles has in practice led to different rates of return on the property, as might be expected. In pre-war days the courts had quite generally come to the conclusion that a return of approximately 6 per cent on the depreciated value of the property was nonconfiscatory and reasonable. ${ }^{3 i}$ In some cases the rate varied somewhat from this figure, owing to local conditions or special circumstances. For several years following 1920, the courts quite generally regarded a rate of 8 per cent as reasonable. ${ }^{38}$ The commissions ${ }^{69}$ also have quite generally acted on this basis. Within the past two or three years, however, there has been a distinct tendency to reduce the rate of return to a point below which confiscation would result. In the Mystic Valley Water Company case ${ }^{20}$ the Connecticut Public Utilities Commission said 5 per cent was reasonable. In the Ohio

35 See Bluefield Water Worles and Improucmont Co. 2. Public Scre. Comm., supra note 14.

${ }^{36}$ Re Advances in Rates, Eastern Case (1911) 20 Inters. Com. Rep. 219; Western Case (1911) 20 Inters. Com. Rep. 307.

${ }_{37}$ Wilcoss v. Consolidated Gas Co., supra note 27; Ccdar Rapids Gas Light Co. v. Cedar Rapids (1912) 223 U. S. 665, 32 Sup. Ct. 389; Des Moines Gas Co. v. Des Moines (1915) 238 U. S. 153, 35 Sup. Ct. 811; Lincoln Gas and Electric Co. v. Lizncoln, supra note 33.

${ }^{8}$ Brush Electric Co. v. Galveston (1923) 262 U. S. 443, 43 Sup. Ct. 606; Lovisiana Water Co. v. Missouri Public Scrvico Commission (1924 C) Pub. Util. Rep. (W. D. Mo.) 293; Re Bronx Gas and Elcctric Co. (1923 A) Pub. Util. Rep. (N. Y. Sup. Ct.) 255.

39 Re Georgia Railway and Power Co. (1921 A) Pub. Util. Rep. (Ga.) 165; Re Lansing Fuel and Gas Co. (1923 C) Pub. Util. Rep. (Ohio) 348; Re Northwestern Ohio Light Co. (1924 B) Pub. Util. Rep. (Ohio) 762; IiC Appalachian Pover Co. (1923 E) Pub. Util. Rep. (W. Va.) 221.

so Re IIystic Valley Water Co. (1925 D) Pub. Util. Rep. (Conn.) 385. 
Utilities Company case ${ }^{41}$ the Supreme Court of the United States said that less than 5 per cent was confiscatory. In the case of the Chesapeake and Potomac Telephone Company ${ }^{12}$ the federal court said 6 per cent was not confiscatory, while $51 / 2$ per cent was considered too low in the case of the Northwestern Bell Telephone Company.43 Seven and one-fourth per cent was declared nonconfiscatory in the Georgia Railway and Power case, ${ }^{44}$ while 7 per cent was just and reasonable in the Rockford Electric Company case ${ }^{45}$ before the Illinois commission. On the other hand, many cases can be cited showing that 8 per cent is still adhered to. The North Dakota Railroad Commissioners ${ }^{40}$ decided that the Mandan Electric Company was entitled to 8 per cent return. The Rhode Island commission ${ }^{47}$ used 8 per cent in the case of the Narragansett Electric Light Company as a basis of calculating losses. The New York commission allowed 8 per cent in the case of Peekskill Light and Railvoad Company. ${ }^{48}$ The Missouri commission said 8 per cent was reasonable for the Capital City Water Company. ${ }^{49}$ The federal court in the case of New York and Richmond Gas Company ${ }^{50}$ has just pointed out that in that part of the country gas companies have been allowed to earn 8 per cent, and that this was necessary to enable the corporations to attract sufficient new capital for extensions and development. These decisions doubtless, to some degree at least, reflect changing conditions in the money market, as well as modifications for local factors, individual credit of the company, and the like. But to one who has even a casual acquaintance with money market conditions the country over many of the differences are irreconcilable on economic grounds. Moreover, rates based on valuation figures apply to securities outstanding, regardless of contracts requiring stipuIated interest and dividend requirements. Enormous sums of capital have been borrowed since 1920 for the development of the

11 Ohio Utilities Co. v. Public Utilities Commission of Ohio (1925 C) Pub. Util. Rep. (U. S.) 599.

42 Chesapeake, and Potomac Tel. Co. v. Whitmon (1925 D) Pub. Util.

Rep. (U. S. D. C. Md.) 407.

${ }^{43}$ Lincoln Division, Northwestern Bell Tel. Co. v. Spillman (1926 A)

Pub. Util. Rep. (U. S. D. C. Neb.) 330.

44 Georgia Railway and Power Co. v. Georgia Railroad Commission (1921)

262 U. S. 625, 43 Sup. Ct. 680.

45 City of Rocleford v. Rockford Electric Co. (1925 D) Pub. Util. Rep. (IIl. Com. Comm.) 154.

${ }_{40}$ Re Mandan Electric Co. (1925 D) Pub. Util. Rep. (N. D. R. R. Comm.) 508.

${ }^{47}$ Public Utilities Commission v. Narragansett Electric Light Co. (1925

D) Pub. Util. Rep. (R. I. P. U. C.) 545.

18 Peekskill v. Peekskill Light and Railroad Co. (1925 D) Pub. Util. Rep.

(N. Y. P. U. C.) 593.

40 Re Capital City Water Co. (1925 D) Pub. Util. Rep. (Mo. Pub. Serv.

Comm.) 41.

${ }_{50}$ New York and Richmond Gas. Co. v. Prendergast, supra note 16. 
public utility business. These sums of necessity were borrowed upon high interest rates; and contracts were undertaken, in most cases under the eyes of the commissions, for years in the future guaranteeing a high return to the holders of those issues. Reduction of rates regardless of contracts outstanding will work injury to these security holders. Capital, like labor and management, demands only the return specified in the contract as the price of its service. In the end it will secure this or it will, like labor and management, withdraw from the field and leave the public without service.

\section{CAPITAL MIARIKET}

The pressing need of regulation is conformity to the modern highly specialized capital market. Originally the capital market was simple and local in character. A knot of friends possessing capital would associate themselves together, pooling their resources in a common undertaking and each assuming the same risk, exercising a voice in the management, and receiving the same reward. The stockholders of the early corporation were to all intents and purposes partners. In this stage of the development of financial organization, the ownership and control of business enterprises were in identical hands. But when business grew to such size that local funds were insufficient to meet requirements for expansion, capital had to be sought from distant sources, in many cases even from abroad. This introduced a division between the owners and managers of capitalistic enterprises. Stockholders residing at a distance became in reality only investors, since although legally they were still the owners of the business, in fact they lacked practical possibility of exercising any influence upon the management. On the other hand, local stockholders, serving as directors and officers, managed the business. With this stage of development the corporation breame a distinctive institution totally different from the old partnership relation. Investors emerged as a distinctive type, performing a specialized function. This class of pure investors has continued to grow, until today it constitutes the larger part of the eapital market. It is this market to which public utility enterprises have to appeal for funds in competition with other enterprises as well as with civil bodies.

The capital market itself has become refined in character. The leading types of issues of public utility operating companies, outside of railroads, are mortgage bonds, debenture bonds, preferred and common stocks. Miortgage bonds are adapted to those desiring to assume only the minimum amount of risk. These issues hold a position of priority of claim as to assets and earnings of the corporation. Their holders in return for this privilege are content with a comparatively low rate of return. Debenture 
bonds and preferred stocks are purchased by those who are in the habit of assuming business risks. The claims of debenture bondholders and preferred stockholders are junior to mortgage bondholders, but offer larger return on the capital thus invested. The common stock of public utility corporations is in a different position from the common stock of industrial enterprises. It is in effect a sort of junior preferred stock, because its income is definitely limited by the fact of regulation. Ordinarily common stockholders in industrial enterprises expect a substantial, if not the greater, part of their reward to come from residual earnings, surpluses, extra and stock dividends, and the like. None of these is likely in the utilities. On the contrary the common stockholder expects for the most part in return for his acceptance of the weakest position of all security holders, a higher rate of return in regular dividends, with possibly some increase in value due to surplus earnings. He has the right to expect that in ordinary times the earnings will be sufficient to cover the requirements of operating expenses and senior capital charges with enough remaining to pay regular dividends on the common at a given rate. In return it is primarily he who accepts the risks of fluctuating business conditions, wars, calamities, wage demands, and even of regulation itself.

Thus properties as such do not compete with each other in the modern capital market as they once did. On the contrary, mortgage bonds of public utilities find themselves in competition with mortgage bonds of other enterprises, with farm and real estate mortgages, and even with civil loans. The amount of assets in relation to the amount of mortgage bonds issued must conform to the accepted standards of safety. So also the margin of earnings over interest requirements for these issues must follow standards recognized in the banking field. If a 50 per cent margin for assets over the bond issue and 75 per cent of earnings over interest requirements are demanded, these standards must be recognized in financing under regulation. Similarly, accepted standards for debenture bonds and preferred stocks must not be ignored if public utility enterprises are to get their portion of current capital funds. Standards for common stock have been fairly well developed through experience in the railroad field; and these may be taken as the guide for other types of public utilities. The precise margin of earnings over dividend requirements is not of great importance in this connection; but a considerable surplus of earnings is a requisite for the sale of common stock and the maintenance of the credit of the corporation. To ignore these conditions of the capital market would be little less than financial suicide. The progress of utilities in the future depends largely upon the willingness of regulation to meet competitive costs in the modera capital market. 